\title{
Community Perceptions of Tourism Impacts on Coastal Protected Areas
}

\author{
Nuria Navarro $\mathbb{D}$ \\ Departamento de Biología y Geología, Física y Química Inorgánica, Universidad Rey Juan Carlos, C/Tulipán s/n, \\ 28933 Móstoles, Spain; nuria.navarro@urjc.es
}

Received: 23 June 2019; Accepted: 12 August 2019; Published: 14 August 2019

\begin{abstract}
The Dominican Republic is one of the countries with the highest growing number of tourists in coastal protected areas. The objective of this study was to examine the perceived impact of tourism on three coastal national parks, involving all the sectors related to these protected areas and tourism. Workshops were carried out in the coastal protected areas studied. The results revealed the poor integration of local communities in the management plans, the lack of information on protected areas, and the poverty of the majority of the resident families despite income of tourism. The findings of this study highlighted the concept of a carrying capacity or threshold for tourism development. Lower to moderate levels of tourism development appeared beneficial, but as tourism development increased, perceptions of the community worsened. The results also confirmed that tourism contributes to environmental degradation, mainly due to contamination of rivers and coastlines, accumulation of waste, and over-exploitation of natural resources. A series of strategies is proposed to minimize this impact.
\end{abstract}

Keywords: coastal areas; tourism impact; management of protected areas; community participation

\section{Introduction}

Tourism is booming throughout Latin America and constitutes the main source of income for the majority of Caribbean countries [1]. The tourism business is based mainly in coastal areas and makes use of natural resources such as sandy beaches, insolation, and specific vegetation associated with the tropics [2]. Because these coastal areas possess such enormous ecological wealth and biodiversity [3], many of them are protected areas.

Tourism in protected areas can be a way to promote the connection of visitors with the values of protected areas, and should establish mutually beneficial relationships between local communities, the protected area, and tourism. However, as reported by $\mathrm{Xu}$ et al. [4], "such ideal relationships are hard to realize when confronted with complex, natural, social, and economic backgrounds". In spite of political statements acknowledging the social and economic importance of tourism and identifying it as an alternative for the development and conservation of protected areas, there is a lack of specific action programs to use as guidelines [5]. Many studies have indicated the negative impact that uncontrolled tourism can have on the environment [6-8]. The effects caused by mass tourism are not limited to the coastal area where they originate but also affect the surrounding areas due to hydrological dynamics and other environmental transport mechanisms [9]. On the other hand, tourism activity in protected areas can benefit local destinations through increased income from the financial contributions of visitors, employment, and direct conservation support [10]. Although the relationship between tourism and protected areas is complex, tourism is almost always a critical component to consider in the management of protected areas [11].

Tourism in the Dominican Republic is the main and most important business [12], especially beach tourism, although protected areas are becoming much more popular. However, there is very 
little planning or control [5]. From 1995 to 2000, tourism gross domestic product (GDP) increased by $12 \%$ every year, compared to $8 \%$ for the rest of the economy [13]. In 2011, tourism accounted for $4.7 \%$ of the GDP, and directly or indirectly supported $14 \%$ of all employment in the country [14]. Due to the poverty that exists in the Dominican Republic, with approximately $45 \%$ of the population under the poverty threshold [15], well-managed tourism could refloat the country's economy. As several authors have stated [16-18], well-managed tourism has major positive economic impacts in rural areas and contributes to poverty reduction [19] in developing countries.

Tourism studies in the Dominican Republic have been analyzed from different perspectives, studying the impacts of ecotourism [20], rural livelihoods [21], tourists' preferences [22], border tourism [23], and cultural and historical tourism [24]. However, empirical research on the impacts of tourism on protected coastal areas of the Dominican Republic is scarce, and it is only recently that some studies on the subject began to be published, such as the impacts generated on the coast and coral reefs [25] and the economic impacts in coastal communities [14].

Effective coastal management must involve citizens in the decision-making process. Public participation should play a central role in sustainability assessment, in order to contribute to policy -and decision-making [26]. Törn et al. [27] found that poor involvement of local communities in the establishment and management of protected areas resulted in unfavorable behavior towards sustainable use of natural resources. Some authors, such as Gursoy and Rutherford [28] and Nicholas et al. [29], recommend the support and participation of the local population to guarantee sustainable tourism in protected areas. Despite the importance of local community participation in the management of protected areas, few studies considering perceptions of communities in Dominican Republic have been published [21,30,31].

In view of these two gaps, this study attempts to analyze the perceived impact of tourism by the local communities, national park personnel, and organizations involved in tourism businesses on three coastal national parks in the Dominican Republic. These coastal national parks have been chosen according to their different tourist development (low, medium, and high). Therefore, the focus of this research was to examine the perception of local communities about the impacts of tourism on the natural values of protected coastal areas with increasing levels of tourism development. The results obtained in this study will be useful for national park managers in order to sustainably manage tourism in protected coastal areas.

\section{Materials and Methods}

The methods used in this study are explained in the following three subsections: the first provides background information on the three coastal national parks where the data were gathered; the second is dedicated to explaining the methodology chosen for identification of the perceived impact of tourism in these protected areas (workshops); the third is devoted to data analysis.

\subsection{Montecristi, Del Este, and Los Haitises National Parks}

The Dominican Republic has a National System of Protected Areas (SINAP) that is regulated by Sectoral Law No. 202-04 of Protected Areas [32]. This law also provides that in all protected areas of the country tourism and ecotourism activities can be developed, but only in a sustainable way. The coastal natural parks are some of the Dominican Republic's most important natural assets, due to their high productivity and biodiversity. This study covers three coastal national parks in the country, namely Montecristi, Los Haitises, and Del Este, as shown in Figure 1. These coastal protected areas have been chosen according to their different tourist development (low, medium, and high; Table 1) for comparison.

\subsubsection{Montecristi National Park}

Located in the North East of the Dominican Republic, the Montecristi National Park borders on Haiti at its easternmost edge (Figure 1). It was classified as a national park by Decree 1315 [33]. 
The territory measures $1309.5 \mathrm{~km}^{2}\left(201 \mathrm{~km}^{2}\right.$ of land and $1108.5 \mathrm{~km}^{2}$ of coastline) [34]. The climate is semi-arid, with an average rainfall of $700 \mathrm{~mm}$ and average temperature of $27^{\circ} \mathrm{C}$. Montecristi is characterized by coral reefs, mangrove forests, and estuaries (Table 1), and it is one of the most important areas from an ecological viewpoint $[35,36]$. Tourism development has not occurred in this area, meaning its natural state has been conserved [13].

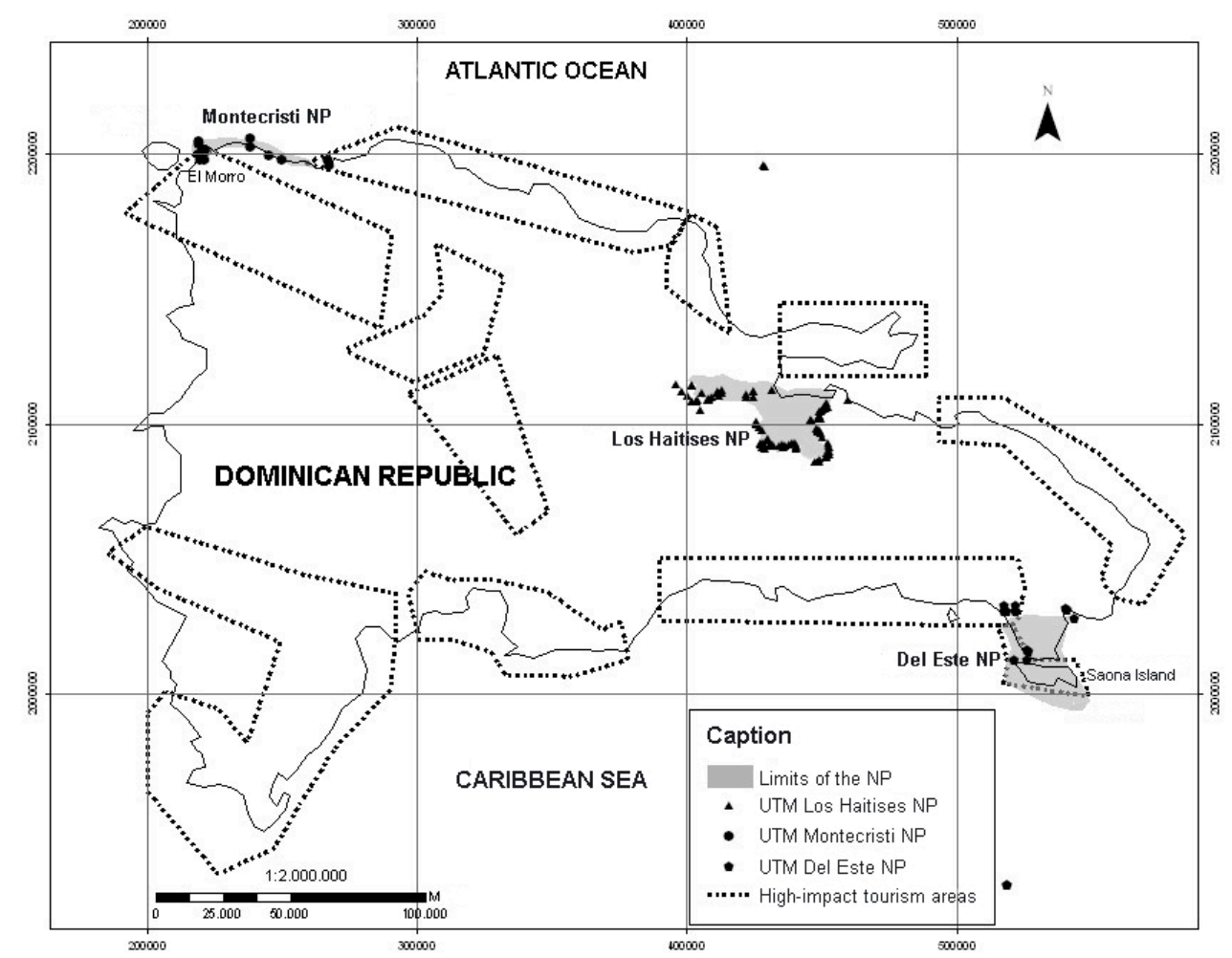

Figure 1. Location of the national parks (NP) studied and UTM (Universal Transverse Mercator) coordinates found in the legislation [32], as well as high-impact tourism areas.

Table 1. Brief description of the national parks studied.

\begin{tabular}{ccccc}
\hline National Park & Coral & Mangrove Cover & Tourism Development & Urban Development \\
\hline Montecristi & Yes & High & Low & Very low \\
Los Haitises & Partially & High & Medium & Low \\
Del Este & Yes & Low & High & High \\
\hline
\end{tabular}

\subsubsection{Los Haitises National Park}

Located in the north east of the Dominican Republic (Figure 1), the park was first protected as a Forestry Reserve in 1968 by Law 244 [37] and declared a national park in 1976 by Law 409 [38]. It currently occupies an area of $600.82 \mathrm{~km}^{2}$. It has a wet tropical climate, with an average rainfall of $1900-2000 \mathrm{~mm}$ per year and an average temperature of $25-26^{\circ} \mathrm{C}$ [39]. Los Haitises is characterized by estuaries, mangrove forests, and small portions of coral reefs [40,41] (Table 1 ). This is an area with medium tourism development (24,000 visitors per year on average [42]) and ecotourism potential given the diversity and proximity of ecosystems [13].

\subsubsection{Del Este National Park}

Located on the southeastern coastline, the park includes the Saona Island in its protection area (Figure 1). It has been protected since 1975 under Decree 1311 [43], occupying approximately $420 \mathrm{~km}^{2}$, which includes the peninsular area $\left(310 \mathrm{~km}^{2}\right)$ and Saona Island $\left(110 \mathrm{~km}^{2}\right)$. The climate is predominantly wet tropical, with an average annual temperature of $24^{\circ} \mathrm{C}$ and average rainfall around $1334 \mathrm{~mm}$ [44]. 
Del Este is characterized by sandy beaches, coral reefs, and cliffs $[45,46]$ (Table 1$)$. The Saona Island beaches are the areas where tourist activity is the highest. Tourism is the primary industry, with more than 250,000 visitors per year on average [42], and there is high potential for the cruise industry [13].

\subsection{Workshops in the National Parks}

The assessment of perceptions among stakeholders regarding tourism impacts was performed by conducting workshops in the three national parks chosen. The perceived impact of tourism on the national parks was identified by observing the changes produced in the physical, natural, and social environments resulting from the activities performed inside the park or the construction of infrastructure within the protected areas. Actions producing a negative effect, as well as those introducing improvements (positive impacts), were taken into account. This identification was made by the participants in the workshops. The methodology implemented first included design and validation of the workshop presentations and the questionnaires aimed at understanding the perceptions of participants, then analysis of the information collected, and finally interpretation according to the objective of this research.

The workshop consisted of a series of presentations introducing the topic to be discussed and the interdisciplinary group work. The presentations had an informative aim to ensure that all participants receive the same information. They were structured into four theme groups with different sections (Table 2). Each section consisted of a presentation of the topic and the key terms used in the questionnaires. The group work took place following the presentations and consisted of discussing the topics of the workshop and completing the questionnaire provided. For the design of questionnaires, three sections with open-ended questions were identified to assess the participants' knowledge of the national parks and their perceptions regarding tourism impacts (Table 3). The first section asked about the borders and zones of the national park. The second section assessed participants' knowledge of the values of the national park (environmental, socio-cultural, and economic values). The third section sought to determine the participants' perceptions of the sources of disturbance associated with tourist infrastructure and tourist activities on environmental, socio-cultural, and economic components potentially affected (or receptors), and the impacts caused by their interactions (identifying negative and positive impacts). At the end of the workshop, there was an explanation of the conclusions of each group and the completed questionnaires were gathered as the basis of the analysis of their perceptions.

The participants in the workshops were invited based on the following criteria: had relations with government bodies, the private sector, or relevant community organizations in the areas studied, had been living in the national park for at least the last 5 years, and were willing to participate in the study. The participating organizations were divided into several categories for subsequent analysis: Tourism (Secretary of State for Tourism and tourism organizations), Academy (universities, lyceums, Academy of Science, and technical training centers), Environment (Secretaries of State for the Environment and Natural Resources, National System of Protected Areas, and environmental non-governmental organizations), and Community (fishing and crabbing associations, local boards, and historical societies). For the workshops, participants were divided into four groups, each one comprising people representing different categories (interdisciplinary groups). The advantage of interdisciplinary groups is the interaction between the participants, since they can build their thoughts upon the contributions made by others [47].

The number of participants in each workshop was different, ranging from 16 to 40 people (Table 4). Although the number of participants was not high, the participants were selected to include all of the sectors related to protected areas, local communities, and tourism to ensure the representativeness of the information obtained in the workshops. Workshops were generally small, allowing everyone some personal attention and the chance to be heard [48]. The park with the highest number of participants was Montecristi and Del Este was the lowest. There was a higher attendance by men than women, with the exception of Del Este, where the percentage of female attendees was double that of their male counterparts. Except for Los Haitises, the majority of participants in Del Este and Montecristi 
belonged to the category Academy, followed by those belonging to Environment, Tourism and, finally, Community (Table 4). At Los Haitises, however, the predominant category was Environment, with no participants from the Academy category, as there are no lyceums or faculties in the region.

Table 2. Presentations structure.

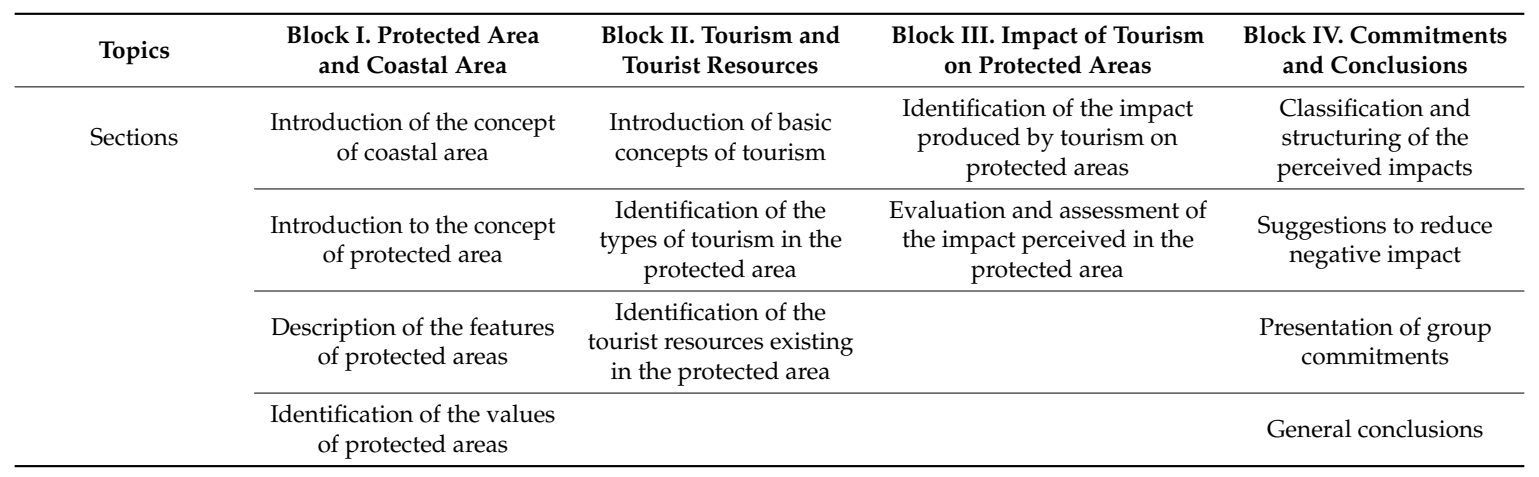

Table 3. Questionnaire structure with the most relevant questions.

\begin{tabular}{|c|c|c|c|}
\hline \multicolumn{4}{|c|}{ Section 1. National Park } \\
\hline \multicolumn{4}{|c|}{ Identify the borders of the National Park } \\
\hline \multicolumn{2}{|c|}{ Identify the zones of the National Park } & $\begin{array}{c}\text { Core area } \\
\text { Where is it? }\end{array}$ & $\begin{array}{l}\text { Buffer zone } \\
\text { Where is it? }\end{array}$ \\
\hline \multicolumn{4}{|c|}{ Section 2. Knowledge of the Values of the National Park } \\
\hline \multirow{7}{*}{$\begin{array}{l}\text { Identify in detail all the } \\
\text { values you know }\end{array}$} & Environmental values & Socio-cultural values & Economic values \\
\hline & Landscape & Traditional identity and activities & Income from tourism \\
\hline & Coastal areas & $\begin{array}{c}\text { Caves (pictographs, petroglyphs, } \\
\text { and carved reliefs) }\end{array}$ & Employment \\
\hline & $\begin{array}{c}\text { Water resources } \\
\text { Soil }\end{array}$ & Museums and cultural activities & \\
\hline & Vegetation & & \\
\hline & Fauna & & \\
\hline & Where are the & re they visited by tourists? & \\
\hline \multicolumn{4}{|c|}{ Section 3. Perceived Impact of Tourism } \\
\hline Identify in detail & $\begin{array}{l}\text { Sources of disturbance } \\
\text { associated with tourist } \\
\text { infrastructure and } \\
\text { tourist activities }\end{array}$ & $\begin{array}{c}\text { Environmental, socio-cultural, } \\
\text { and economic values (receptors) } \\
\text { potentially affected by sources } \\
\text { of disturbance }\end{array}$ & $\begin{array}{l}\text { Negative and positive impacts } \\
\text { caused by the sources of } \\
\text { disturbance on the receptors }\end{array}$ \\
\hline
\end{tabular}

Table 4. Number $(\mathrm{N})$ and percentage of participants of the national parks workshops.

\begin{tabular}{|c|c|c|c|c|c|c|c|c|}
\hline & \multicolumn{2}{|l|}{ Montecristi } & \multicolumn{2}{|l|}{ Los Haitises } & \multicolumn{2}{|l|}{ Del Este } & \multicolumn{2}{|l|}{ Total } \\
\hline & Percentage (\%) & $\mathbf{N}$ & Percentage (\%) & $\mathbf{N}$ & Percentage (\%) & $\mathbf{N}$ & Percentage (\%) & $\mathbf{N}$ \\
\hline Men & 62.5 & 25 & 80.0 & 16 & 31.2 & 5 & 60.5 & 46 \\
\hline Women & 37.5 & 15 & 20.0 & 4 & 68.7 & 11 & 39.5 & 30 \\
\hline \multicolumn{9}{|l|}{ Categories } \\
\hline Tourism & 17.5 & 7 & 15.0 & 3 & 12.5 & 2 & 15.8 & 12 \\
\hline Environment & 25.0 & 10 & 80.0 & 16 & 37.5 & 6 & 42.1 & 32 \\
\hline Community & 15.0 & 6 & 5.0 & 1 & 6.2 & 1 & 10.5 & 8 \\
\hline Academy & 42.5 & 17 & 0.0 & 0 & 43.7 & 7 & 31.6 & 24 \\
\hline
\end{tabular}

\subsection{Data Analysis}

The data acquired from the open-ended questions (questionnaire) were analyzed in several steps. First, Excel was used to organize the questionnaire responses manually, indicating the sources of disturbance, the receptors potentially affected, and the perceived impacts. Means values of the percentage of participants that perceived positive and negative impacts for each national park were determined, and the resulting values were subjected to a one-way ANOVA with Tukey HSD (Honestly Significant Difference) post hoc comparisons. Data were visualized quantitatively with bar charts. 


\section{Results}

The results are presented according to the questionnaire sections explained above.

\subsection{Identification of Boundaries and Zones of the National Parks}

The results obtained in the first section of the questionnaires (boundary and zones of the national park) highlighted the lack of knowledge of the borders and zones of the protected areas by all the participants. The definition of the borders found in the legislation (Sectorial Law on Protected Areas 202-04 [32]) were UTM (Universal Transverse Mercator) coordinates, which are not understood by the local population. These UTM coordinates have been revised and it was confirmed that in the cases of the Montecristi and Los Haitises National Parks, the perimeter is well defined, whereas in Del Este National Park, the points are marked in an area of the peninsula that does not correspond to the perimeter of the protected area (Figure 1).

\subsection{Knowledge of the Values of the National Parks (Environmental, Socio-Cultural, and Economic Values)}

The results obtained in Montecristi showed that this park has serious problems relating to the lack of basic infrastructure for the local population, highlighting the absence of sewerage, waste collection, and water purification systems. Due to the semi-arid temperatures (average temperature of $27^{\circ} \mathrm{C}$ ) and low rainfall (average rainfall of $700 \mathrm{~mm}$ ) in the area there is substantial concern about its water resources. The most important ecosystems in Montecristi are the dry forests, keys, mangroves, freshwater wetlands, coastal lakes, coral reefs, marine prairies, and sand dunes. All the workshop participants reported that the main natural assets are mangrove forests, coral reefs, beaches, keys, and El Morro (a $242 \mathrm{~m}$ promontory, the highest on the north-east coastline).

In Los Haitises the results showed that the main natural and socio-cultural assets are mangrove forests, rain forests, estuaries, coastal lakes, beaches, and caves with pre-Columbian pictographs and petroglyphs. Due to the limestone in the terrain, there are as many courses of aboveground water covering the park as canals, pools, and underground water courses. In spite of its level of protection, there are numerous population centers in the area. The main economic activities are agriculture, livestock, fishing activities, transformation industries, and tourism. The questionnaires revealed that the main problem at Los Haitises relates to internal management. When the area was protected and the land expropriated from farmers to include it in the park's core area, other lands were not given in exchange and there were no alternative means of subsistence proposed. It is the protected area with the most disputes as to soil use. Its history features episodes of continuous eviction of people from the park area, who have become "environmental refugees" [49]. In addition, the isolation of the area prevents regional development and there is a low level of family income. Additionally, there has been a shift from a farming economy of subsistence to a speculative economy [40]. The main cause of this impact has been farming migration, consisting of the clearing and burning of small plots of natural forest, the fallow period, and the repeating of this cycle. This type of agriculture has become speculative migrating agriculture that features an interruption in the fallow period with the planting of short-term crops, mainly yautía (Xanthusoma sagittisaliun) in vast extensions of land [50]. This form of agriculture has changed the use of the soil, which together with the aggressive nature of the practice, has produced enormous changes in the national park. The vegetation suffering the most from this impact are the mangroves, which are disappearing in certain areas. The situation gives rise to major disputes between the park communities, the government, and the protected area.

Del Este is an area of enormous biodiversity that supports a high degree of tourism pressure, with more than 250,000 visitors per year on average [42], which makes this natural park the most visited of the entire system of protected areas. The landscape is distinct, with coral reefs, sandy beaches, mangroves, rocky coastline, broad-leaf forests, interior lakes, and caves with pre-Columbian pictographs and petroglyphs, all of them well-identified by the workshop participants. The results obtained from the questionnaires highlighted that the land included in the park limits previously belonged to the local 
communities. The farmers that suffered from expropriation were not compensated nor offered any type of program relating to alternative economies of subsistence. Many farmers, therefore, continue to work the land inside the park unlawfully, and continue clearing forests for charcoal production and hunting illegally. Due to the absence of alternative economies, the majority of local inhabitants have abandoned their traditional activities (fishing, agriculture, and cattle raising) and are now involved exclusively in the tourism sector.

\subsection{Perception of the Impact (Negative and Positive) of Tourist Infrastructure and Tourist Activities on Environmental, Socio-Cultural, and Economic Values of the National Parks}

In the three national parks, the perceived positive tourism impacts were related to the spreading and promotion of the park's natural values amongst visiting tourists, the greater awareness for protection, as well as the generation of employment and revenue for the local communities. The percentage of participants who perceived positive impacts was the highest $(p<0.05)$ in Montecristi (with low tourism development) and was lowest in Del Este (with high tourist development, Figure 2). The percentage of participants who perceived negative impacts was similar in the three national parks (Figure 2).

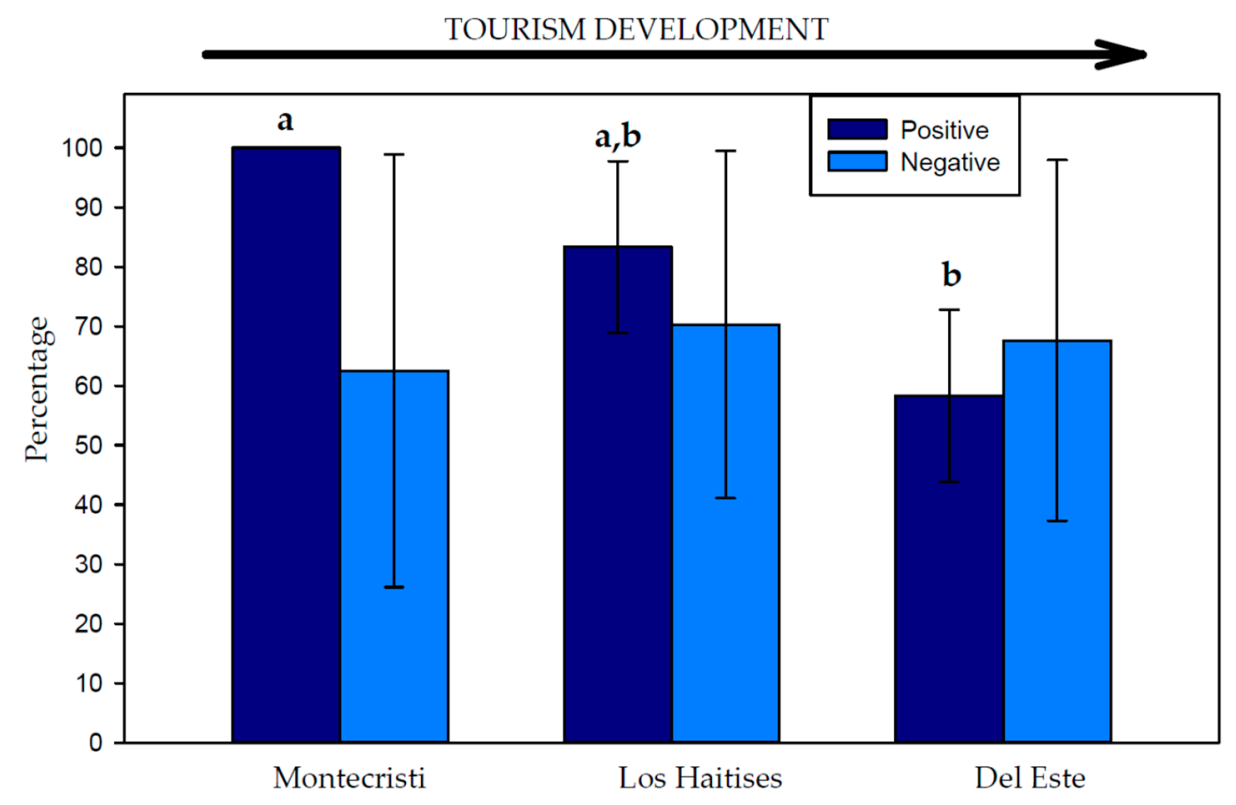

Figure 2. Percentage of participants that perceived positive and negative impacts in each national park. Error bars show standard deviation. Values of positive impacts with the same letter are not significantly different $(p>0.05)$ according to a post hoc Tukey HDS (Honestly Significant Difference) test and analysis of variance (ANOVA). Values of negative impacts are not significantly different $(p>0.05)$.

The workshop participants perceived 11 sources of disturbance associated with tourism that affected environmental, socio-cultural, and economic receptors, producing 23 negative impacts (Table 5). Results show that the perceived negative tourism impacts constantly highlighted in the three national parks were surface and underground water contamination (perceived by $100 \%$ of the participants), coastal water contamination (100\%), sewage pollution (no treatment plants, $100 \%$ ), and accumulation of waste in unsuitable areas (93\%) (Figure 3). Other negative impacts perceived by a high percentage of participants were damage or disturbance to marine fauna and vegetation by motorboats (74\%), decrease in fisheries resources by overexploitation $(63 \%)$, and disturbance to fauna by noise or light pollution (58\%). There were, however, differences in the impacts perceived and in the degrees of perception between the different national parks (Table 5). 
Table 5. Negative impacts perceived by the workshop participants in the National Parks. The sources of disturbance associated with tourism, the environmental, socio-cultural, and economic receptors potentially effected, and the perceived negative impacts are shown. The percentage of participants who perceive the negative impact is indicated (the rest of the participants did not perceive the impact).

\begin{tabular}{|c|c|c|c|c|c|c|}
\hline Sources of Disturbance & Receptors & & Negative Impact & $\begin{array}{c}\text { Percentage } \\
\text { Montecristi (\%) }\end{array}$ & $\begin{array}{c}\text { Percentage Los } \\
\text { Haitises (\%) }\end{array}$ & $\begin{array}{l}\text { Percentage Del } \\
\text { Este }(\%)\end{array}$ \\
\hline \multirow[t]{5}{*}{$\begin{array}{l}\text { Construction of } \\
\text { infrastructure }\end{array}$} & $\begin{array}{c}\text { Environmental/Vegetation (V), Fauna } \\
\text { (F), Landscape (L) }\end{array}$ & 1 & Habitat loss & 25 & 75 & 50 \\
\hline & Environmental/L, Coastal Areas (CA) & 2 & Visual impact (large number of boats in beaches) & 0 & 0 & 100 \\
\hline & Environmental/Water (W) & 3 & Decrease in water resources & 25 & 0 & 100 \\
\hline & Environmental/Soil (S) & 4 & Loss of soil/loss of soil structure & 0 & 25 & 50 \\
\hline & Environmental/L, W & 5 & Sewage pollution (no treatment plants) & 100 & 100 & 100 \\
\hline Accumulation of waste & Environmental/L, CA & 6 & Waste in unsuitable areas & 100 & 75 & 100 \\
\hline \multirow[t]{6}{*}{ Contamination } & Environmental/W & 7 & $\begin{array}{l}\text { Surface and underground water contamination } \\
\text { (affects public health) }\end{array}$ & 100 & 100 & 100 \\
\hline & Environmental/CA & 8 & $\begin{array}{l}\text { Coastal water contamination (damage or } \\
\text { disturbance to coastal habitats) }\end{array}$ & 100 & 100 & 100 \\
\hline & Environmental/S & 9 & Soil contamination by chemical substances & 0 & 75 & 25 \\
\hline & Environmental/V, CA & 10 & Damage to vegetation & 25 & 0 & 0 \\
\hline & Environmental/F, CA & 11 & Damage or disturbance to marine fauna & 25 & 75 & 0 \\
\hline & Environmental/F & 12 & Damage or disturbance to terrestrial fauna & 25 & 50 & 0 \\
\hline \multirow[t]{2}{*}{ Deforestation } & Environmental/V, F, CA & 13 & Habitat loss & 25 & 25 & 25 \\
\hline & Environmental/S & 14 & Soil erosion & 0 & 25 & 0 \\
\hline Plant/animal collection & Environmental/V, F & 15 & Damage to fauna and vegetation & 0 & 100 & 50 \\
\hline \multirow[t]{2}{*}{ Trails } & Environmental/S & 16 & Soil compaction (trampling) & 0 & 100 & 0 \\
\hline & Environmental/V & 17 & Damage to vegetation & 0 & 100 & 0 \\
\hline High-speed motorboats & Environmental/CA, V, F & 18 & $\begin{array}{c}\text { Damage or disturbance to marine fauna and } \\
\text { vegetation }\end{array}$ & 100 & 0 & 100 \\
\hline $\begin{array}{l}\text { Over-exploitation fishery } \\
\text { resources }\end{array}$ & Environmental/CA, F & 19 & Decrease in resources & 100 & 0 & 50 \\
\hline $\begin{array}{l}\text { Increased noise and/or light } \\
\text { pollution }\end{array}$ & Environmental/CA, F & 20 & Disturbance to fauna & 75 & 50 & 25 \\
\hline $\begin{array}{l}\text { Acculturation of receiving } \\
\text { communities }\end{array}$ & Socio-cultural & 21 & Loss of traditional identity & 25 & 50 & 50 \\
\hline \multirow[t]{2}{*}{ Tourism revenues } & Economic & 22 & $\begin{array}{l}\text { Changes in the local economy (replacement of } \\
\text { traditional activities by services) }\end{array}$ & 0 & 0 & 75 \\
\hline & Economic & 23 & Privatization of beaches & 0 & 0 & 50 \\
\hline
\end{tabular}




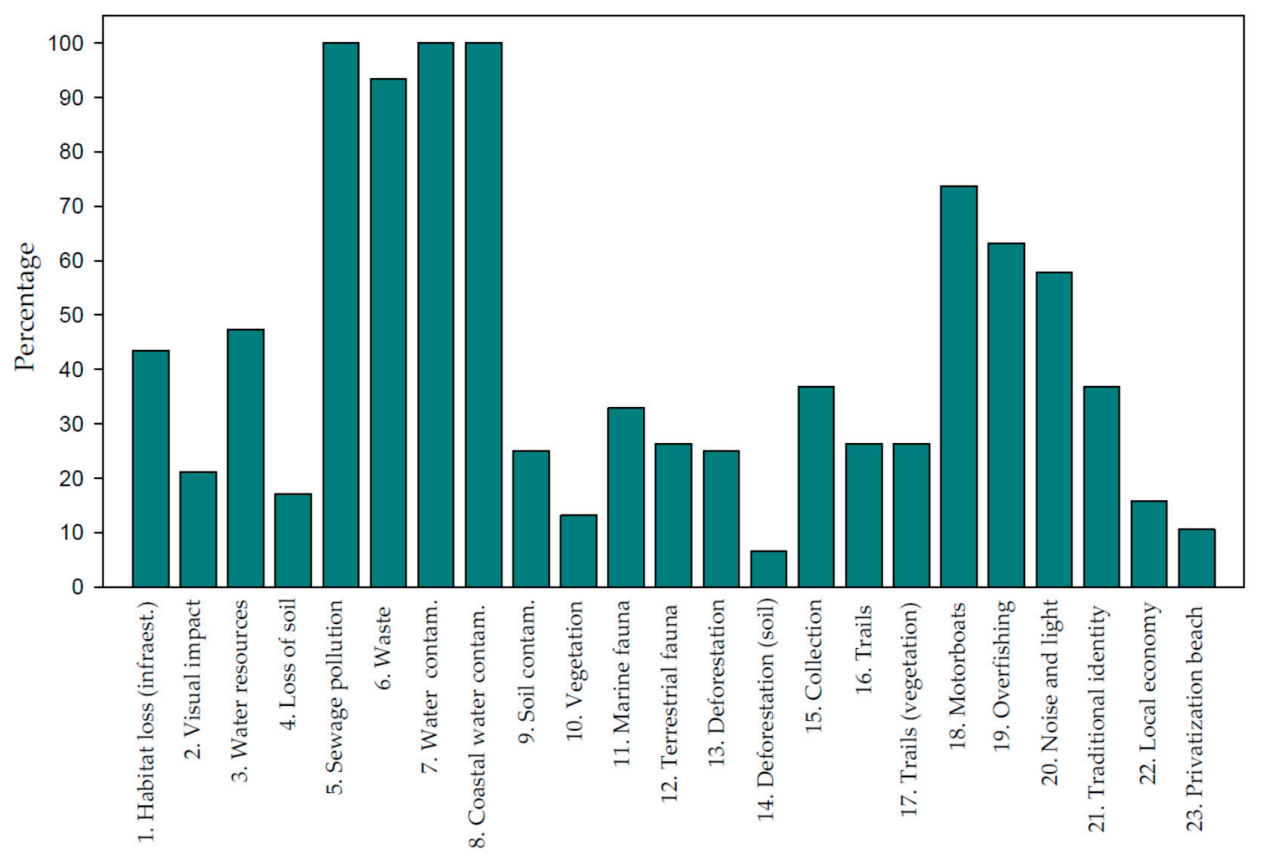

Figure 3. Percentage of participants that perceived each negative impact in the three national parks studied (the rest of the participants did not perceive the impact). Numbered impacts explained in Table 5.

\subsubsection{Montecristi National Park}

In Montecristi National Park the current tourism pressure is low, largely due to the relative isolation of the area, which means that the impact of tourism is not very noticeable. With a high poverty rate, the regional economy is practically based on subsistence, so tourism therefore constitutes a hope for the local inhabitants to improve their economy. However, the tourism that exists has not been planned and there has been no control over construction (Figure 4) or the services offered [36]. The main impacts of tourism in Montecristi perceived by $100 \%$ of the workshop participants relate to pollution, mainly of water, the uncontrolled accumulation of waste, due to its effects on natural resources and public health in the region, and the over-exploitation of fishery resources (Table 5). The water is polluted by solid waste as well as by chemicals from agriculture and fishing vessels. The lack of water purification systems has worsened the situation for the local population, as drinking water is scarce. Pollution is concentrated in seawater, which has an extremely negative effect on the critical habitats, such as the mangrove forest and coastal areas, directly affecting the local fauna [35]. Due to the lack of waste collection sites, waste accumulates in unsuitable areas and produces a great deal of contamination. The over-exploitation of fishery resources is also causing serious problems. Captures usually involve hand-held nets, hooks, and traps, often using chemical substances such as chlorine and gasoline. This negatively affects the surrounding habitat, as well as all of the species of vegetation and animals in the area. In addition, many of the species captured are of vital importance to the health and balance of the reef ecosystems [51]. Furthermore, the collection of bubíes (Sterna fuscata and Anous stolidus) and sea turtle (Caretta, Chelonia mydas, Eretmochelys imbricada, Dermochelys coriacea) eggs for consumption [52] and the collection and trade of ornamental marine species has increased in recent years, due to growing tourism (Table 5). All of the participants also identified high-speed motorboats as another source of impact (Table 5). Their propellers damage the Antillean manatee (Trichechus manatus manatus), they also produce noise, and there is high risk of collisions as well. In addition, poor management of water resources and deforestation have accelerated soil erosion processes. The sediment carried by the water courses resulting from eroding slopes has substantially increased. This sediment accumulates in coastal areas, thus preventing the development of marine flora and fauna. It also changes the light conditions due to its turbidity, which affects different species of 
vegetation, such as the meadows of marine phanerogams (mainly Thalassia testudinum and Syringodium filiforme), resulting in their disappearance.
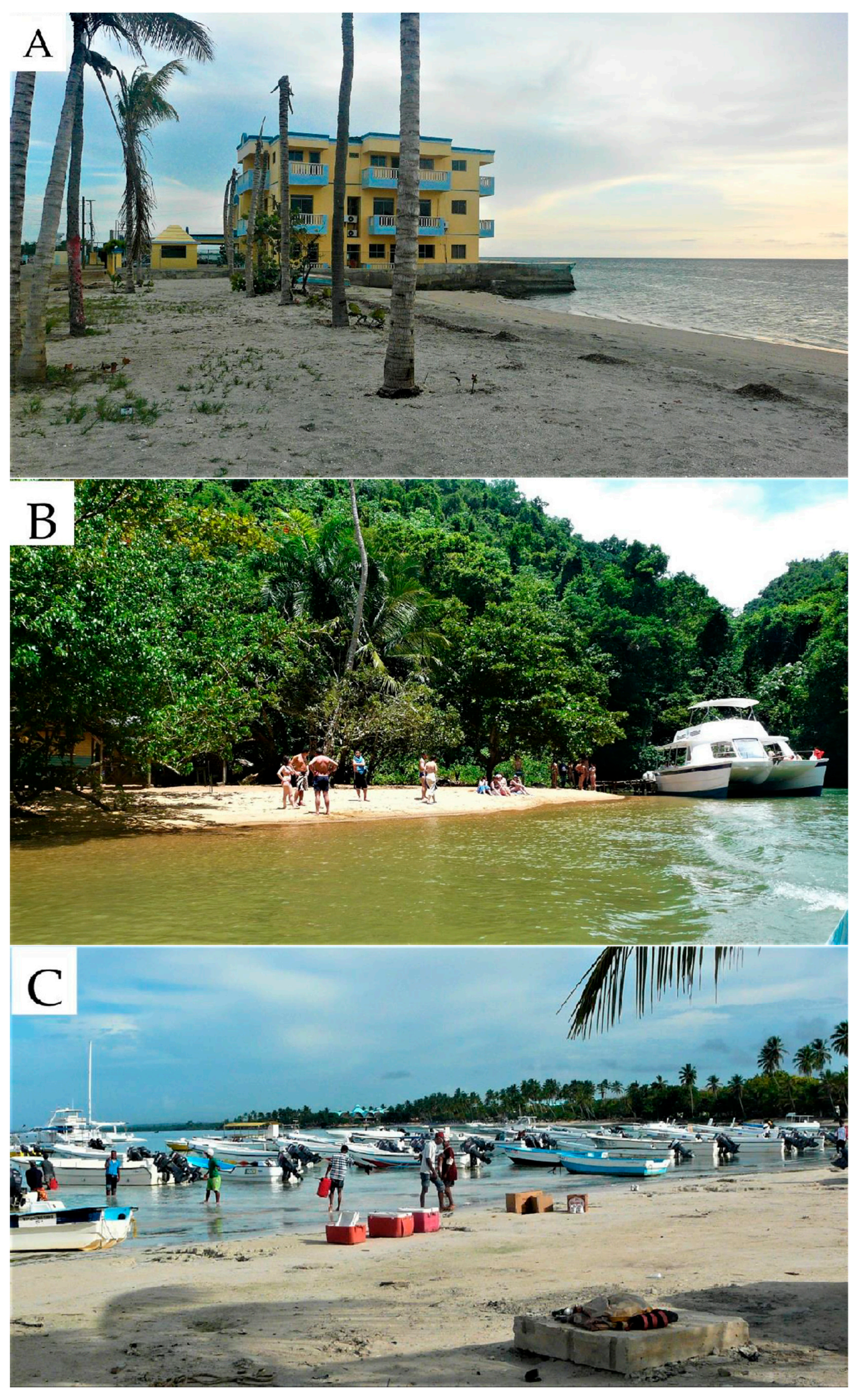

Figure 4. The pictures show different national parks. (A) Construction without planning permission in Montecristi National Park. (B) Uncontrolled access by tourists in Los Haitises National Park. (C) High concentration of boats for tourism in Del Este National Park. 
For many of the local inhabitants at Montecristi, tourism provides hope for the local economy. As indicated previously, both infrastructure and tourism are considered by all the workshop participants to have positive impacts, given that they contribute to covering the needs of visitors and the enjoyment and knowledge of the area's natural values. However, due to the economic situation, many people see the park as an obstacle to the total exploitation of its resources. This is worsened by the fact that very few education and information campaigns about the national park have been carried out.

\subsubsection{Los Haitises National Park}

At Los Haitises National Park, all of the workshop participants considered the accumulation of waste in unsuitable areas and the pollution in the Samaná Bay as high (Table 5). Constant episodes of contamination are due to hydrocarbon spillages by the vessels, solid waste contamination, agricultural chemical products, etc. The contamination of streams and rivers has a serious negative effect on the fauna and flora that inhabit the area. All of this pollution accumulates in the waters of the bay and the beaches, in addition to degrading critical habitats such as the mangroves. Nevertheless, the exact degree of the pollution of surface and ground waters is unknown, mainly due to the absence of basic infrastructure to collect and purify water and the breach of relevant legislation [32]. The generation of waste and absence of collection services damages the landscape, contaminates the environment, and affects the health of the local people, as highlighted by the answers in the questionnaires (Table 5). The increase in tourism pressure in recent years has made the problem worse, as it requires the construction of accommodation and leisure facilities, ignoring the need for basic systems, such as water and electricity supply, and sewage and waste treatment plants. Los Haitises has a complex but not well constructed network of trails. Their compulsory use is aimed at preventing uncontrolled access to other areas of the park, and thus limits the impact from trampling and disposal of waste. Despite this, uncontrolled access to the park is frequent, as perceived by all of the participants (Figure 4, Table 5), and in addition, many visitors take plants and seeds unlawfully, which has a highly aggressive impact on the vegetation (Table 5).

As previously stated, the perception by the workshop participants of the impact of tourism in Los Haitises from a socio-cultural perspective is positive, given that it is seen as a way of generating income, cultural exchange between visitors and local people, and the possibility of furthering knowledge of the park's natural resources. However, $50 \%$ of the participants were concerned about loss of local identity and values (Table 5). It is interesting to observe that the inhabitants of the local communities of Los Haitises are completely in favor of the declaration of a protected area. They acknowledge the need to protect the park in order to attract more visitors, which constitutes the main source of revenue in the region. The fact that the park occupies an enormous extension of land, as well as the lack of studies, has resulted in poor management of the protected area.

\subsubsection{Del Este National Park}

The tourism pressure at Del Este National Park is concentrated in specific areas, such as Saona Island and Bayahibe. Bayahibe, formerly a fishing village, has been transformed into an area largely dependent on ferrying tourists along the coast to Saona Island. All if the workshop participants highlighted that the concentration of boats transporting tourists is so high that the beaches cannot be used for leisure purposes (Figure 4, Table 5). The beaches had daily traffic of over 100 boats (between 10 and 30 passengers each). In addition, motorboats are another form of impact that generates pollution due to the loss of fuel. Tides move the pollution from one area of the park to another, and therefore worsen the problem. The gathering of animal and vegetable species as souvenirs or their sale on the black market, the use of high-speed motorboats, and forms of fishing such as trawling and the use of pots and harpoons are prohibited. Nevertheless, they still take place unlawfully, which is seen as an impact by $50 \%$ of the workshop participants (Table 5). Overfishing and hunting have depleted populations of fish, lobster (Palinurus elephas), lambí (Strombus gigas), mollusks, and white-crowned doves (Columba leucocephala), which are in danger of extinction. 
The workshop participants perceive the impact produced by tourism, but only consider the conservation of Del Este National Park as necessary if it continues to attract visitors. As mentioned previously, the positive effects of tourism are identified as the economic benefits and the spreading by tourism of the area's natural assets. However, the benefits obtained from tourism have not resulted in improvements in the protected area and the construction of infrastructure to attract visitors has promoted the privatization of beaches and generated pollution of different kinds-acoustic, waste, etc. Accordingly, the main negative effects perceived are accumulation of waste in uncontrolled dumps (perceived by $100 \%$ of participants), effects on landscape by unsuitable infrastructure (50-100\%), high concentration of motorboats on the beaches $(100 \%)$, replacement of traditional activities by services $(75 \%)$, and water contamination (100\%, Table 5). Tourism pressure and economic interests in the area are high, especially on the coast, prevailing over the need to preserve its resources. Results confirm that hotels and tourist infrastructure continue to be built within the confines of the national park. The large hotel complexes negatively alter the landscape and generate sewage pollution due to the lack of treatment plants (Table 5). The majority of hotel complexes are located on the coast and have privatized the beaches adjoining their infrastructures, closing them for exclusive use by their clients and preventing access to the local people, which is seen as an impact by $50 \%$ of the workshop participants (Table 5). In addition, no measures have been taken to minimize the impact generated by tourism activities, as shown in the results of the workshops, as there is no legislation regulating large complexes within this national park [44]. The organization of tours and the sites visited are inadequate and poorly prepared for the massive influx of visitors, often exceeding their maximum capacity and producing serious negative effects on the surrounding environment.

\section{Discussion}

This study has found that none of the participants were able to define the borders of the national parks or their different zones. It is important to provide this information on the parks to the local communities and national parks workers, which could be the main beneficiaries. The three national parks studied, especially Los Haitises, occupy large extensions of land. One fundamental issue in efficiently managing the parks is dividing them into sub-areas: core, transition, and buffer areas. Valuable ecological resources are preserved in core areas, which are surrounded by buffer areas and transition areas characterized by increasing intensity of human use. This could make the different uses of soil compatible depending on the area $[53,54]$, and could enable the co-existence of different activities, such as conservation, education, leisure, tourism, management, and research, as well as different combinations thereof.

Nevertheless, the majority of the participants were able to identify the main natural and cultural values of the national parks, whose preservation was the objective justifying their designation as a protected area, while only participants from Los Haitises National Park had a clear opinion about the declaration of protected areas. Public awareness about marine and coastal protected ecosystems, as well as the benefits they provide to society and threats to their existence, is currently low in the Dominican Republic, and an effort to improve public awareness, both through the educational system and more broadly, is needed [1]. It should also be highlighted that as part of their conclusions, the participants were thankful for the workshops, as they "provided us with further knowledge on the parks and their resources". Environmental knowledge is an important variable that affects the level of environmental engagement [55]. In addition, they appreciated the possibility of expressing their opinion on park management, a right that despite being included in current legislation, is not exercised in practice. The importance given by all participants to the promotion of more conservation and information regarding the parks should be highlighted. This shows that social awareness and the lobbying pressure that could be generated to change the situation currently faced by the parks is very high. It is essential to involve the local communities in protected area plans and programs to improve the sustainable use of the environment. Recent studies in marine protected areas [56] indicate that knowledge of the local environmental resources facilitates locals' participation in community-based ecotourism management. 
Organized community groups are one of the most essential elements for community-based coastal management, although these initiatives must be seen as long term efforts [57].

The national parks studied showed different degrees of tourism pressure and different levels of intensity in the use of the area by tourists. Montecristi, a protected area with low economic activity and low tourism development, is the only national park where residents have high expectations for future tourism development, and therefore have more favorable perceptions towards tourism. Lower to moderate levels of tourism development appeared beneficial, but as tourism development increased, perceptions of residents took a downward trend [58]. Long et al. [59] posited that attitudes toward tourism may become more negative when there are higher levels of tourism, as observed in Del Este National Park. Certain tourist activities focused in specific locations within the parks should be highlighted, as they may easily lead to over-exploitation. The situation is worsened by the fact that the basic infrastructure is deficient, without sewerage or water purification systems. As mentioned by Dixon et al. [60], environmental pressures depend on factors such as the number of tourists, the activities they undertake, and the presence or absence of infrastructure, such as wastewater treatment plants. An increase in tourism in these territories without such services for the inhabitants would worsen the quality of water even more, and therefore the quality of life of the inhabitants [61].

It is relevant to point out that the main negative impacts perceived by all the participants are located on the coastal areas (coastal water contamination, waste in beaches, damage or disturbance to marine fauna and vegetation by contamination and high-speed motorboats, over-exploitation of fishery resources, etc.), despite being protected areas. As Eastwood et al. [25] assert, in tourism booms undeveloped and rural coastal areas are often negatively affected by stressors such as discharge of sewage directly into rivers or coastal waters and accumulation of trash and waste in natural ecosystems. Some of these problems could be resolved with a well-defined policy of management and preservation of the land and marine environments [62]. The management of fishery resources and the repopulation of overexploited areas is therefore particularly important [63], as well as the restoration and rehabilitation of natural resources in the coastal zones. Therefore, one of the greatest challenges facing coastal managers is how to integrate tourism development within the ambit of coastal management, and thus increase the likelihood of long-term sustainability of the coast as a whole [64]. Preventing degradation of the coastal zone requires control over access (to control demand), effective planning that pays due attention to the values of ecological services, and rigorous environmental legislation that is properly enforced [65].

As mentioned before, there were some negative tourism impacts, such as water contamination, waste in unsuitable areas, and lack of sewage treatment, which were perceived by all participants in the three national parks. These results are in agreement with previous findings [66-69], which showed the same community perceptions regarding tourism development in national parks. There were, however, differences in the perception of other negative impacts between the three parks. This highlights the importance of understanding the local context in designing management plans and regulations. In Montecristi National Park, participants were particularly concerned about over-exploitation of fisheries resources, since much of the local economy is based on fishing. Another negative impact that also concerned all participants in Montecristi was the disturbance and damage caused to the Antillean manatee by high-speed motorboats, despite being protected by law. Furthermore, some negative impacts appear to be linked to tourism intensity, as they have only been perceived in parks with medium or high tourism development. In Los Haitises National Park (medium tourism development), the participants perceived the negative impacts produced by trails (soil compaction by trampling and damage to vegetation), as well as the impact of the unlawful collection of plants and seeds by tourists. However, these impacts were not perceived in Montecristi, which has less tourist visitors. In Del Este National Park (high tourism development), most participants perceived the negative impacts produced by the construction of tourism infrastructure, since there is great tourism infrastructure building up in the park, something that does not happen in Los Haitises or Montecristi. In addition, Del Este was the 
only park where participants perceived the negative impacts on economic receptors, mainly related to the replacement of traditional activities (fishing, agriculture, and cattle raising) by tourism services.

Another relevant aspect is that the three national parks are located in areas where poverty is severe [15]. The existing problems have arisen because the local communities in the parks were not taken into consideration, nor were economic alternatives proposed for their development when the parks were established. Local inhabitants are, therefore, attracted more by the prospects of a better short term economy based on tourism than by the sustainable use and management of the natural resources, even though this would result in improved conditions in the long term. Nevertheless, most of the residents of these protected coastal areas still live in poverty, despite the income of tourism, as highlighted by the participants of Del Este, the national park with more tourist development. In addition, this income is not being used to improve conditions at the local level, which contributes to an increase in the impact and degradation of the area. A further aspect to be considered is that tourism is rapidly increasing in these coastal protected areas, but without any planning or control. Therefore, it is essential for the government to pass relevant laws for effective infrastructure and construction control. Specific investments are needed for important environmental infrastructure, such as wastewater treatment and solid waste management facilities. In this way, some of the main negative impacts detected by all participants could be solved, such as lack of drinking water, sewage pollution, and accumulation of waste in unsuitable areas. The tourism of the future could be a cooperative enterprise in which a consortium of active players (local communities, industry managers, government, and visitors) share in responsibilities and rewards [70]. In this way, cooperative management must commit to the sustainable development of tourism resources, so that their operations can lead to the generation of jobs for local communities and the conservation of natural and cultural resources. Increased community involvement in management and economic support from government has provided economic improvement for communities and sustainable use of resources in some protected areas $[56,71-74]$.

More detailed studies are required on each national park, especially to determine the best ecological boundaries and to establish a land-use-zoning system. Furthermore, it is necessary to implement the use of management plans for Del Este, Montecristi, and Los Haitises National Parks. These plans constitute the basic instruments for correct management of all protected areas and should contain recommendations, preventive, corrective, and compensatory measures that contribute to minimizing the impacts of tourism identified in this study. It is necessary that a wide range of fields, such as environmental and social sciences, coastal zone management, policy analysis, education, legislation and economics, are considered when managing tourism in protected coastal areas, as well as involving local communities.

\section{Conclusions}

The results of this study support the concept of a carrying capacity or threshold for tourism development $[58,59]$. Local communities in Montecristi and Los Haitises National Parks, with low and moderate levels of tourism development, respectively, have favorable perceptions towards tourism. However, in Del Este National Park, which has increased tourism development, perceptions of the community have worsened. However, the findings also indicate that local communities perceive degradation of these coastal protected areas due to impacts caused by tourist infrastructure and tourist activities, regardless of tourism development. Other issues emerging as a result of these findings are that these local communities are neither getting involved in the decision-making processes regarding these coastal protected areas, nor are they receiving favorable economic benefits from tourism. Based on these results, several strategies can be suggested that may have implications for protected coastal zone management and tourism development. First, local capacity building needs to be improved through education and training. These needs include the human and institutional capacity necessary to monitor and evaluate environmental problems, enforce regulations, and to operate and maintain environmental infrastructure in the protected areas. Second, development of controlled ecotourism can be diversified 
based on the natural and cultural characteristics of each coastal national park. To avoid concentration of tourism in one particular area, as currently happens in Saona Island and Bayahibe (Del Este National Park), there is a need to promote tourism to other locations as well. Third, interaction, communication, and coordination between decision makers and local communities should be improved. Therefore, local training on the principles of co-management and local communication campaigns about the national parks values and regulations should be implemented in collaboration with the national parks management committees. Fourth, conservation and protection of natural and cultural resources should improve, as well as the treatment of solid waste and wastewater. Finally, financial support and creation of jobs for local communities should be established and benefits from tourism should be used for rational distribution of development and conservation costs of these coastal protected areas.

Funding: This research was funded by the Spanish Agency for International Development Cooperation (AECID), grant number C/011340/07.

Acknowledgments: I would like to thank the Autonomous University of Santo Domingo, especially Marcos Morales, for helping with the organization of the workshops; the Secretary of State for the Environment and Natural Resources and the Secretary of State for Tourism in the Dominican Republic for their support; and Virginia Tejero for helping with the elaboration of maps. I would also like to thank all participants in the workshops. This manuscript was enhanced and clarified thanks to the valuable comments and suggestions of four anonymous reviewers.

Conflicts of Interest: The author declares no conflict of interest.

\section{References}

1. Wielgus, J.; Cooper, E.; Torres, R.; Burke, L. Coastal Capital: Dominican Republic. Case Studies on the Economic Value of Coastal Ecosystems in the Dominican Republic; World Resources Institute: Washington, DC, USA, 2010; p. 42.

2. Rivera-Monroy, V.H.; Twilley, R.R.; Bone, D.; Childers, D.L.; Coronado-Molina, C.; Feller, I.C.; Herrera-Silveira, J.; Jaffe, R.; Mancera, E.; Rejmánková, E.; et al. A Conceptual Framework to Develop Long-Term Ecological Research and Management Objectives in the Wider Caribbean Region. BioScience 2004, 54, 843. [CrossRef]

3. Windevoxhel, N.R.J.; Lahmann, E. Situation of integrated coastal zone management in Central America: Experiences of the IUCN wetlands and coastal zone conservation management. Oceans Coast. Manag. 1999, 42, 257-282. [CrossRef]

4. Xu, J.; Lü, Y.; Chen, L.; Liu, Y. Contribution of tourism development to protected area management: Local stakeholder perspectives. Int. J. Sustain. Dev. World Ecol. 2009, 16, 30-36. [CrossRef]

5. FAO/PNUMA. Tourism in the National Parks and other protected areas of Latin America; FAO: Santiago, Chile, 1993.

6. Green, H.; Hunter, C.; Moore, B. Application of the Delphi technique in tourism. Ann. Tour. Res. 1990, 17, 270-279. [CrossRef]

7. Hardy, A.; Beeton, R. Sustainable Tourism or Maintainable Tourism: Managing Resources for More Than Average Outcomes. J. Sustain. Tour. 2001, 9, 168-192. [CrossRef]

8. Huybers, T.; Bennett, J. Environmental Management and the Competitiveness of Nature-Based Tourism Destinations. Environ. Resour. Econ. 2003, 24, 213-233. [CrossRef]

9. Torres-Bejarano, F.; González-Márquez, L.C.; Díaz-Solano, B.; Torregroza-Espinosa, A.C.; Cantero-Rodelo, R. Effects of beach tourists on bathing water and sand quality at Puerto Velero, Colombia. Environ. Dev. Sustain. 2018, 20, 255-269. [CrossRef]

10. Ardoin, N.M.; Wheaton, M.; Bowers, A.W.; Hunt, C.A.; Durham, W.H. Nature-based tourism's impact on environmental knowledge, attitudes, and behavior: A review and analysis of the literature and potential future research. J. Sustain. Tour. 2015, 23, 838-858. [CrossRef]

11. Eagles, P.F. Trends in Park Tourism: Economics, Finance and Management. J. Sustain. Tour. 2002, 10, $132-153$. [CrossRef]

12. Padilla, A.; McElroy, J.L. The Tourism Penetration Index in Large Islands: The Case of the Dominican Republic. J. Sustain. Tour. 2005, 13, 353-372. [CrossRef]

13. Ruta, G. Coastal Zones Management and Tourism in the Dominican Republic; World Bank: Washington, DC, USA, 2003. 
14. Duffy, L.N.; Stone, G.; Charles Chancellor, H.; Kline, C.S.; Reis, A.C. Tourism development in the Dominican Republic: An examination of the economic impact to coastal households. Tour. Hosp. Res. 2016, 16, 35-49. [CrossRef]

15. Gabinete Social, Oficina Nacional de Planificación. Strategy for Poverty Reduction in the Dominican Republic; Gabinete Social, Oficina Nacional de Planificación: Santo Domingo, Dominican Republic, 2003.

16. Ashley, C.; Boyd, C.; Goodwin, H. Pro-Poor Tourism: Putting Poverty at the Heart of the Tourism Agenda. In Natural Resources Perspectives; Overseas Development Institute: London, UK, 2000; Volume 51.

17. Roe, D.; Ashley, C.; Page, S.; Meyer, D. Tourism and the Poor: Analysing and Interpreting Tourism Statistics from a Poverty Perspective; Pro-Poor Tourism (PPT) Working Paper; Department for International Development: London, UK, 2004; Volume 16.

18. Valdivieso, J.; Eagles, P.; Gil, J. Efficient management capacity evaluation of tourism in protected areas. J. Environ. Plann. Manag. 2015, 58, 1544-1561. [CrossRef]

19. Snyman, S. Strategic Community Participation in Sustainable Tourism. In Environmental Challenges and Solutions; Springer Science and Business Media LLC: Berlin, Germany, 2016; Volume 2, pp. 65-80.

20. Castellanos-Verdugo, M.; Vega-Vázquez, M.; Oviedo-García, M.Á.; Orgaz-Agüera, F. The relevance of psychological factors in the ecotourist experience satisfaction through ecotourist site perceived value. J. Clean. Prod. 2016, 124, 226-235. [CrossRef]

21. León, Y.M. The impact of tourism on rural livelihoods in the Dominican Republic's coastal areas. J. Dev. Stud. 2007, 43, 340-359. [CrossRef]

22. Mercado, L.; Lassoie, J.P. Assessing Tourists' Preferences for Recreational and Environmental Management Programs Central to the Sustainable Development of a Tourism Area in the Dominican Republic. Environ. Dev. Sustain. 2002, 4, 253-278. [CrossRef]

23. Del Río, J.A.J.; Agüera, F.O.; Cuadra, S.M.; Morales, P.C. Satisfaction in border tourism: An analysis with structural equations. Eur. Res. Manag. Bus. Econ. 2017, 23, 103-112. [CrossRef]

24. Pérez Gálvez, J.; López-Guzmán, T.; Orgaz Agüera, F.; Prada-Trigo, J. Análisis de los turistas que visitan una Ciudad Patrimonio de la Humanidad. El caso de Santo Domingo, República Dominicana. Rosa Ventos Tur. Hosp. 2017, 9, 605-622. [CrossRef]

25. Eastwood, E.K.; Clary, D.G.; Melnick, D.J. Coral reef health and management on the verge of a tourism boom: A case study from Miches, Dominican Republic. Ocean Coast. Manag. 2017, 138, 192-204. [CrossRef]

26. Kristjánsdóttir, K.R.; Ólafsdóttir, R.; Ragnarsdóttir, K.V. Stakeholder participation in developing sustainability indicators for a European Northern periphery tourism system. J. Rural Community Dev. 2017, 12, $210-235$.

27. Törn, A.; Siikamäki, P.; Tolvanen, A.; Kauppila, P.; Rämet, J. Local people, nature conservation, and tourism in northeastern Finland. Ecol. Soc. 2007, 13, 8.

28. Gursoy, D.; Rutherford, D.G. Host attitudes toward tourism: An Improved Structural Model. Ann. Tour. Res. 2004, 31, 495-516. [CrossRef]

29. Nicholas, L.N.; Thapa, B.; Ko, Y.J. Residents' perspectives of a world heritage site: The Pitons Management Area, St. Lucia. Ann. Tour. Res. 2009, 36, 390-412. [CrossRef]

30. MacLeod, D.V. Parks or people? National parks and the case of Del Este, Dominican Republic. Prog. Dev. Stud. 2001, 1, 221-235. [CrossRef]

31. Oviedo-García, M.Á.; Vega-Vázquez, M.; Castellanos-Verdugo, M.; Orgaz-Agüera, F. Tourism in protected areas and the impact of servicescape on tourist satisfaction, key in sustainability. J. Destin. Mark. Manag. 2019, 12, 74-83. [CrossRef]

32. Official State Gazette. Sectoral Law on Protected Areas, No. 202-04; Official State Gazette: Santo Domingo, Dominican Republic, 2004.

33. Official State Gazette. Decree 1315; Official State Gazette: Santo Domingo, Dominican Republic, 1983.

34. Silva, M. Trabajo de Delimitación del Parque Nacional Montecristi. Informe Final; Dirección Nacional de Parques: Santo Domingo, Dominican Republic, 1983.

35. Gef-Pnud/Onaplan. Conservación y Manejo de la Biodiversidad en la Zona costera de la Republica Dominicana. Proyecto Biodiversidad. Informe Final. Subcontrato Biología Marina. Parque Nacional de Montecristi; Gef-Pnud/Onaplan: Santo Domingo, Dominican Republic, 1998. 
36. Gef-Pnud/Onaplan. Conservación y Manejo de la Biodiversidad en la Zona costera de la Republica Dominicana. Proyecto Biodiversidad. Informe Final. Subcontrato Apoyo a programa pequeños subsidios a ONG's del FMAM (Programas Innovativos). Parque Nacional de Montecristi; Gef-Pnud/Onaplan: Santo Domingo, Dominican Republic, 1998.

37. Official State Gazette. Law 244; Official State Gazette: Santo Domingo, Dominican Republic, 1968.

38. Official State Gazette. Law 409; Official State Gazette: Santo Domingo, Dominican Republic, 1976.

39. Gef-Pnud/Onaplan. Conservación y Manejo de la Biodiversidad en la Zona costera de la Republica Dominicana. Proyecto Biodiversidad. Informe Final. Subcontrato Los Haitises. Parque Nacional Los Haitises; Gef-Pnud/Onaplan: Santo Domingo, Dominican Republic, 1997.

40. Agencia Española de Cooperación Internacional. Plan de Uso y Gestión del Parque Nacional Los Haitises y Áreas periféricas; Dirección Nacional de Parques; Agencia Española de Cooperación Internacional: Madrid, Spain, 1991.

41. Gef-Pnud/Onaplan. Conservación y Manejo de la Biodiversidad en la Zona costera de la Republica Dominicana. Proyecto Biodiversidad. Informe Final. Subcontrato Los Haitises. Muestreeos Biológicos en el Parque Nacional Los Haitises. Parque Nacional Los Haitises; Gef-Pnud/Onaplan: Santo Domingo, Dominican Republic, 1997.

42. Secretary of State for the Environment and Natural Resources. National Program for the Valorization of Protected Areas; Secretary of State for the Environment and Natural Resources: Santo Domingo, Dominican Republic, 2004.

43. Official State Gazette. Decree 1311; Official State Gazette: Santo Domingo, Dominican Republic, 1975.

44. Silva, M.; Mateo, J.; Núñez, F.; Sánchez, N.; Grasela, K.; Rodríguez, S.; Domínguez, E.; Bonnelly, I. Plan de Conservación de Sitio. Parque Nacional del Este; Amigo del Hogar: Santo Domingo, Dominican Republic, 2006.

45. Belando, A.L. Request of Inclusion of Parque Nacional del Este and its buffer zone in the list of The Word Humanity Heritage; Dominican Republic Government. Secretaria de Medio Ambiente y Recursos Naturales: Mexico City, Mexico, 2001.

46. Seve, J. Valoración Económica de Áreas Protegidas: Metodología y Estudio de Caso Parque Nacional del Este; USAID/República Dominicana, Subsecretaría de Áreas Protegidas y Biodiversidad, Secretaría de Estado de Medio Ambiente y Recursos Naturales: Santo Domingo, Dominican Republic, 2001.

47. Claiborne, P. Community Participation in Tourism Development and the Value of Social Capital. Master's Thesis, University Gothenburg, Gothenburg, Sweden, 2010.

48. Pavelin, K.; Pundir, S.; Cham, J.A. Ten Simple Rules for Running Interactive Workshops. PLoS Comput. Boil. 2014, 10, 1003485. [CrossRef] [PubMed]

49. Geisler, C. A New kind of trouble: Evictions in Eden. Int. Soc. Sci. J. 2003, 175, 69-78. [CrossRef]

50. Hernández, R. Cultivo de Yautia; Fundación de Desarrollo Agropecuario: Santo Domingo, Dominican Republic, 1996.

51. Lirman, D.; Schopmeyer, S.; Huntington, B.; Thyberg, T.; Gough, M.; Gough, T.; Gough, R.; Gough, Y.; Bowden-Kerby, A.; Bowden-Kerby, A. A window to the past: Documenting the status of one of the last remaining 'megapopulations' of the threatened staghorn coral Acropora cervicornis in the Dominican Republic. Aquat. Conserv. Mar. Freshw. Ecosyst. 2010, 20,773-781. [CrossRef]

52. Latta, S.; Rimmer, C.; Keith, A.; Wiley, J.; Raffaele, H.; McFarlan, K.; Fernandez, E. Birds of the Dominican Republic and Haiti; Princeton University Press: Princeton, NJ, USA, 2006.

53. Agardy, M.T. Advances in marine conservation: The role of marine protected areas. Trends Ecol. Evol. 1994, 9, 267-270. [CrossRef]

54. Batisse, M. Development and Implementation of the Biosphere Reserve Concept and Its Applicability to Coastal Regions. Environ. Conserv. 1990, 17, 111-116. [CrossRef]

55. Barr, S.; Gilg, A.W. A conceptual framework for understanding and analyzing attitudes towards environmental behaviour. Geogr. Ann. Ser. B Hum. Geogr. 2007, 89, 361-379. [CrossRef]

56. Masud, M.M.; Aldakhil, A.M.; Nassani, A.A.; Azam, M.N. Community-based ecotourism management for sustainable development of marine protected areas in Malaysia. Ocean Coast. Manag. 2017, 136, 104-112. [CrossRef]

57. Jorge, M.A. Developing capacity for coastal management in the absence of the government: A case study in the Dominican Republic. Ocean Coast. Manag. 1997, 36, 47-72. [CrossRef]

58. Johnson, J.D.; Snepenger, D.J.; Akis, S. Residents' perceptions of tourism development. Ann. Tour. Res. 1994, 21, 629-642. [CrossRef] 
59. Long, P.T.; Perdue, R.R.; Allen, L. Rural Resident Tourism Perceptions and Attitudes by Community Level of Tourism. J. Travel Res. 1990, 28, 3-9. [CrossRef]

60. Dixon, J.; Hamilton, K.; Pagiola, S.; Segnestam, L. Tourism and the Environment in the Caribbean. In Environment Department Papers; The World Bank: New, York, NY, USA, 2001; Volume 80.

61. Secretary of State for the Environment and Natural Resources. Methodological Guide for the Development and/or Updating of Protected Areas Management Plans of the Dominican Republic; Secretary of State for the Environment and Natural Resources: Santo Domingo, Dominican Republic, 2006.

62. Ormazábal, C. National Systems of Protected Wild Areas in Latin America; FAO Technical Document, No. 3; FAO: Santiago, Chile, 1988; pp. 1-205.

63. Castilla, J.C. The future Chilean Network of Marine Parks and Reserves and the concepts of conservation, preservation and management in national legislation. Rev. Chil. Hist. Nat. 1996, 69, 253-270.

64. Hall, C.M. Trends in ocean and coastal tourism: The end of the last frontier? Ocean Coast. Manag. 2001, 44, 601-618. [CrossRef]

65. Davenport, J.; Davenport, J.L. The impact of tourism and personal leisure transport on coastal environments: A review. Estuar. Coast. Shelf Sci. 2006, 67, 280-292. [CrossRef]

66. Herrera, M.R.G.; Sasidharan, V.; Hernández, J.A.Á.; Herrera, L.D.A. Quality and sustainability of tourism development in Copper Canyon, Mexico: Perceptions of community stakeholders and visitors. Tour. Manag. Perspect. 2018, 27, 91-103. [CrossRef]

67. Gier, L.; Christie, P.; Amolo, R. Community perceptions of scuba dive tourism development in Bien Unido, Bohol Island, Philippines. J. Coast. Conserv. 2017, 21, 153-166. [CrossRef]

68. Zahedi, S. Tourism impact on coastal environment. Urban Transp. 2007 2008, 99, 45-57.

69. Zarifsanayei, A.; Sanayei, H.Z.; Zand, S.M. Challenges Ahead of Integrated Coastal Zone Management in Environmentally Sensitive Islands: A Case Study. Asian J. Water, Environ. Pollut. 2018, 15, 69-80. [CrossRef]

70. Farrell, B.H. Cooperative tourism and the coastal zone. Coast. Zone Manag. J. 1986, 14, 113-130. [CrossRef]

71. Campbell, S.J.; Kartawijaya, T.; Yulianto, I.; Prasetia, R.; Clifton, J. Co-management approaches and incentives improve management effectiveness in the Karimunjawa National Park, Indonesia. Mar. Policy 2013, 41, 72-79. [CrossRef]

72. Alexander, K.; Ramotadima, M.; Sanderson, C.E. The power of consensus: Developing a community voice in land use planning and tourism development in biodiversity hotspots. Ecosyst. Serv. 2018, 30, 350-361. [CrossRef]

73. Rakotomahazo, C.; Ravaoarinorotsihoarana, L.A.; Randrianandrasaziky, D.; Glass, L.; Gough, C.; Todinanahary, G.G.B.; Gardner, C.J. Participatory planning of a community-based payments for ecosystem services initiative in Madagascar's mangroves. Ocean Coast. Manag. 2019, 175, 43-52. [CrossRef]

74. Thiao, D.; Westlund, L.; Sambe, B.; Diadhiou, H.D.; Dème, M.; Mbenga, A.; Diop, M. A perception-based participatory monitoring and evaluation approach to foster effective co-management of the marine protected areas in Northwest Africa. Ocean Coast. Manag. 2019, 175, 1-16. [CrossRef]

(C) 2019 by the author. Licensee MDPI, Basel, Switzerland. This article is an open access article distributed under the terms and conditions of the Creative Commons Attribution (CC BY) license (http://creativecommons.org/licenses/by/4.0/). 